\title{
PRIMARY SQUAMOUS CELL CARCINOMA ARISING FROM THE PELVIC RETROPERITONEUM
}

\author{
Min Ji Ryu, MD, Ye Won Chung, MD, Hyo Sook Bae, MD, Jae Kwan Lee, MD, PhD, Nak Woo Lee, MD, PhD, \\ Jae Yun Song, MD, PhD \\ Department of Obstetrics and Gynecology, Korea University College of Medicine, Seoul, Korea
}

Primary retroperitoneal squamous cell carcinoma is very rare. A 66-year-old woman presented with right leg edema and pain that had developed one month prior. Pelvis magnetic resonance imaging showed the presence of a mass around the iliac vessels invading the iliacus muscle, right femoral head and obturator muscle. The patient underwent an exploratory laparotomy but the mass was not completely removed. The patient was treated with concurrent chemoradiation therapy with paclitaxel-carboplatin and Tomotherapy three weeks after surgery. After that, she conducted a further seven cycles of different chemotherapy. A abdomen CT scan after the last seven cycles showed a reduction in the size of the primary mass from 7.2 to $6.6 \mathrm{~cm}$, consistent with a partial response to treatment. As a result, the role of adjuvant chemotherapy in these tumors is controversial. And it is considered that complete resection is more important.

Keywords: Primary retroperitoneal neoplasms; Squamous cell carcinoma; Concurrent chemoradiation therapy

Primary retroperitoneal tumors are defined as solid or cystic tumors, whether benign or malignant, that develop in the retroperitoneal space and arise from lymphatic, nervous, vascular, support muscle, connective, or fibroareolar tissue independent of the organs and large vessels in the space $[1,2]$. Primary retroperitoneal neoplasms account for only $0.1 \%-0.2 \%$ of all malignancies [3]. About $80 \%-86 \%$ of retroperitoneal tumors are malignant. And most primary retroperitoneal neoplasms are lymphomas, liposarcomas, leiomyosarcomas and malignant histiofibromas [3,4]. Whereas Epithelial cancer of the retroperitoneum is extremely rare, with only a few cases having been reported [5]. We present a case of a primary squamous cell carcinoma (SCC) of the pelvic retroperitoneum which to our knowledge has been rarely described.

\section{Case Report}

A 66-year-old woman, gravida 4, para 2, visited our hospital with right leg edema and right inguinal pain that had developed one month prior. The patient had a past medical history of hypertension and the patient had taken medication three years prior. Duplex color Doppler ultrasound did not demonstrate the presence of a thrombus or a Baker's cyst. Gynecologic ultrasound was undertaken for the evaluation of a pelvic mass and $5.4 \times 3.1 \mathrm{~cm}$ sized pelvic mass was discovered on the right side pelvic wall apart from the uterus and ovary. Pelvis magnetic resonance imaging (MRI) showed the presence of a $7.2 \mathrm{~cm}$ sized lobulating contoured, heterogeneous enhanced mass in the right pelvic cavity which suggested the presence of a retroperitoneal soft tissue tumor, such as a sarcoma or malignant nerve sheath tumor (Fig. 1). A Pap smear, chest $\mathrm{X}$-ray, gastroscopy, and colonoscopy were normal. Tumor

Received: 2012.6.27. Revised: 2012.8.16. Accepted: 2012.8.24. Corresponding author: Jae Yun Song, MD, PhD

Department of Obstetrics and Gynecology, Korea University Anam Hospital, Korea University College of Medicine, 73 Inchon-ro, Seongbuk-gu, Seoul 136-705, Korea Tel: +82-2-920-6775 Fax: +82-2-920-5357

E-mail: yuni105@korea.ac.kr

This is an Open Access article distributed under the terms of the Creative Commons Attribution Non-Commercial License (http://creativecommons.org/licenses/ by-nc/3.0/) which permits unrestricted non-commercial use, distribution, and reproduction in any medium, provided the original work is properly cited.

Copyright (c) 2012. Korean Society of Obstetrics and Gynecology 


\section{KOREAN JOURNAL OF OBSTETRICS \& GYNECOLOGY}

Min Ji Ryu, et al. Retroperitoneal squamous cell carcinoma

markers are normal except SCC antigen which was elevated to $10.47 \mathrm{ng} / \mathrm{mL}(\mathrm{N}, 0-1.5 \mathrm{ng} / \mathrm{mL})$.

The patient underwent an exploratory laparotomy. There was a $7 \times 5 \mathrm{~cm}$ sized retroperitoneal hard mass fixed to the right pelvic wall compressing the external iliac artery and vein. The inner portion of the mass was necrotic and the mass was attached tightly to the iliac vessels. There was no lesion on the uterus, ovary and upper abdominal organs. It was impossible to remove the total mass completely for the risk of great vessel injury and a frozen biopsy suggested the presence of a squamous cell carcinoma (Fig. 2). Because the ${ }^{18} \mathrm{~F}$-fluorodeoxyglucose positron emission tomography scanning $\left({ }^{18} \mathrm{~F}-\mathrm{FDG} \mathrm{PET} / \mathrm{CT}\right)$ scan that was obtained 2 days after the operation revealed no uptake elsewhere and pelvic retroperitoneum was determined as the primary site (Fig. 3). The patient underwent concurrent chemoradiatiotherapy (CCRT) treatment with the use of paclitaxel-carboplatin and Tomotherapy three weeks after surgery. Paclitaxel $\left(135 \mathrm{mg} / \mathrm{m}^{2}\right.$ over 3 hours on day 1) and carboplatin $\left(350 \mathrm{mg} / \mathrm{m}^{2}\right.$ on day 1$)$ were administered every

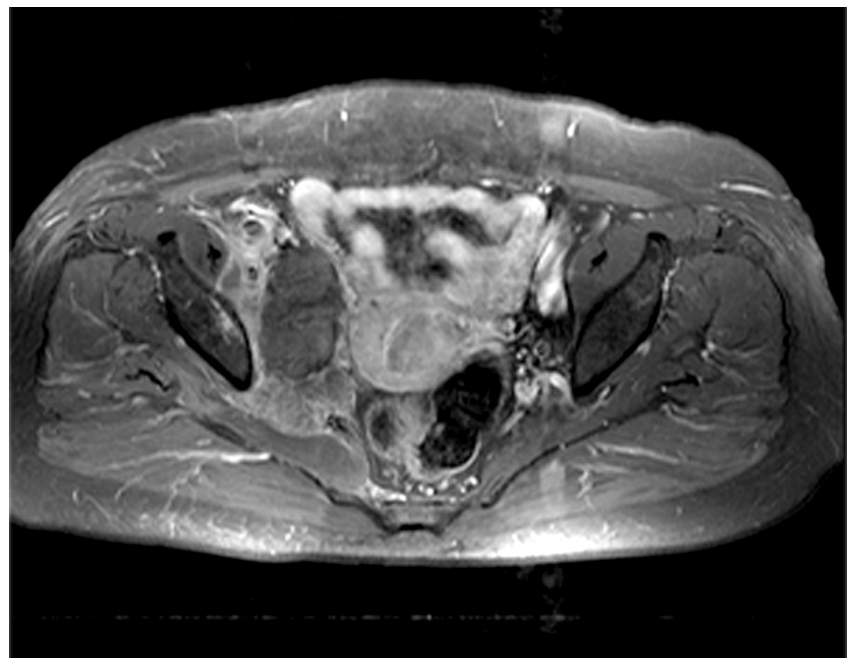

Fig. 1. Magnetic resonance imaging showed the presence of a heterogeneous mass with an ill-defined margin that measured $7.2 \mathrm{~cm}$. Focal calcification that infiltrated the iliacus muscle, femoral head and obturator muscle was observed. three weeks.

Three months after completing CCRT, SCC antigen level decreased to $0.33 \mathrm{ng} / \mathrm{mL}(\mathrm{N}, 0-1.5 \mathrm{ng} / \mathrm{mL})$. An abdomen CT scan that was obtained 3 months after the CCRT revealed the total mass size was decreased (right pelvic wall mass, 7.2-6.6 cm) and the inner necrotic portion was increased and metastatic mass on iliac artery was decreased $(2.6-1.1 \mathrm{~cm})$. The patient is well tolerated and right leg edema is improved. After the CCRT, partial response was achieved. For that reason, she received further three cycles of chemotherapy with paclitaxel $\left(175 \mathrm{mg} / \mathrm{m}^{2}\right.$, day 1$)$ and carboplatin (350 mg/m² day 1). According to the $C T$, they were confirmed to be the remnant tumor mass around the right pelvic wall and iliac artery. In addition to these treatments, she underwent four cycles of combination chemotherapy with cisplatin $\left(80 \mathrm{mg} / \mathrm{m}^{2}\right.$, day 1) and 5 -fluorouracil $\left(1,000 \mathrm{mg} / \mathrm{m}^{2}\right.$, from day 1 to 4$)$. Three weeks after completion of the chemotheraphy, there is no change in the abdomen CT scan. And SCC was within the normal range. The patient refused the above management. Neither a primary lesion nor any signs of recurrence were demonstrated for four years after the operation. To date, the patient has been followed with no evidence of recurrence.

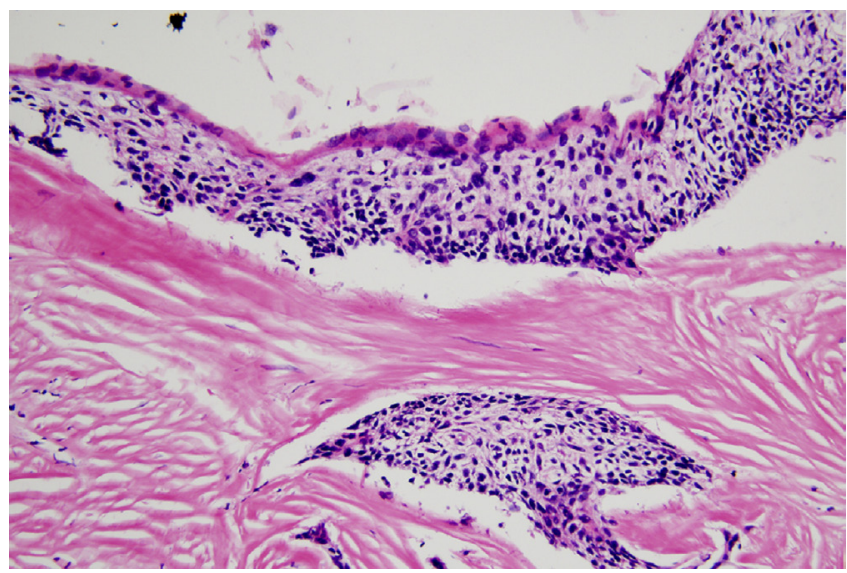

Fig. 2. Microscopic findings of the tumor are shown. A squamous cell carcinoma with intercellular bridges and island infiltrating fibrous tissue is seen $(H \& E, \times 200)$.

Table 1. Reported cases of diseases with a primary retroperitoneal SCC

\begin{tabular}{|llccccc|}
\hline Case & Pathology & Tx & Age of patient (yr) & Year & Author \\
\hline 1 & Retroperitoneal SCC & & 1964 & Shimura et al. [6] \\
2 & Retroperitoneal SCC & Operation & 61 & 2000 & Liu et al. [7] \\
3 & Retroperitoneal SCC & Operation & 57 & 2005 & Khalil et al. [8] \\
This case & Retroperitoneal SCC & Operation, CCRT, adjuvant CTx & 66 & 2012 & Ryu et al. \\
\hline
\end{tabular}

Tx, treatment; SCC, squamous cell carcinoma; CCRT, Combined chemotherapy and radiation therapy; CTx, chemotherapy. 


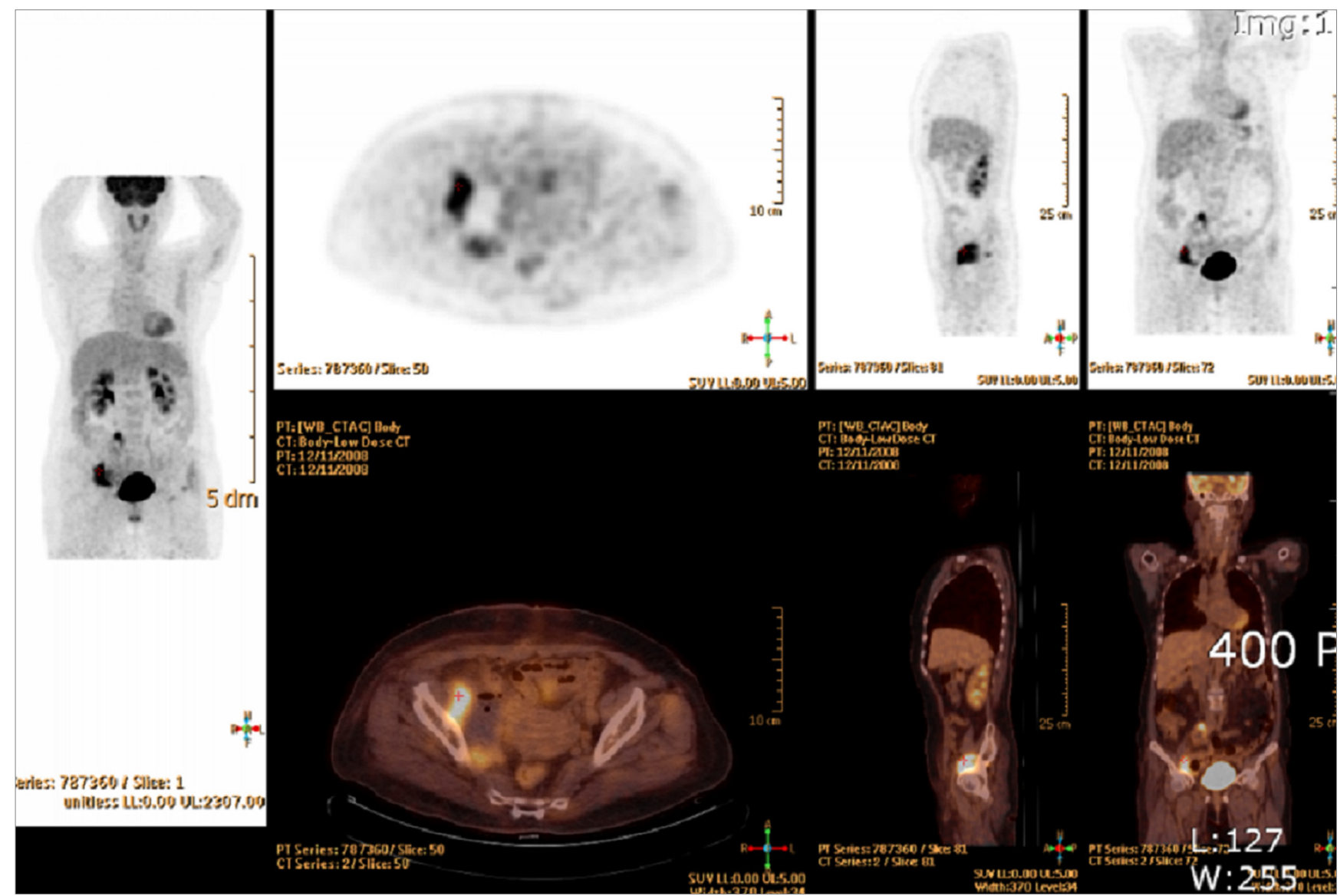

Fig. 3. ${ }^{18} \mathrm{~F}$-fluorodeoxyglucose positron emission tomography showed the presence of a hypermetabolic residual tumor at the right common iliac and pelvic region with invasion to the right acetabulum.

\section{Discussion}

Retroperitoneal neoplasms are rare and comprise a diverse group tumors. To our knowledge, only a few similar cases have been reported (Table 1). Primary retroperitoneal tumors arise in the retroperitoneal space independently of any organ. Secondary retroperitoneal tumors occur by direct extension of any adjacent malignancy or by metastases of malignancies from any tumor in the body [9]. For retroperitoneal tumors, malignant tumors are more frequent than benign tumors and a lymphoma is the most common malignant tumor. Other possible retroperitoneal tumors are germ cell tumors, metastatic carcinomas and soft tissue sarcomas [5]. The most common type of vascular involvement of a retroperitoneal tumor is for the vein only, and both artery and vein involvement is the most infrequent type [10]. Primary retroperitoneal tumors also include tumors caused by embryonic rests of the urogenital ridge (wolffian or mullerian ducts, germ cells) and the primitive notochord and those arising from the neural crest, such as paragangliomas in the organ of Zuckerkandl or at other sites, and retroperitoneal extra-adrenal neuroblastomas $[11,12]$.

Late diagnosis of primary retroperitoneal tumors is common because the retroperitoneum space is adaptable and the tumors remain asymptomatic for some time [11]. MRI, in this case is very useful. The main advantage of MRI is that the tumor can be studied in all planes of the space. And theses image provides a preoperative interpretation of the anatomy, structure and vascularization of the tumor.

The importance of the complete resection is directly related to the possibility of survival [13]. But the rate of complete radical resection has been reported as only $44.5 \%$ in some studies, although reconstruction of the iliac vessels might be required [14]. Due to the rarity and poor prognosis of primary retroperitoneal tumors, there is no well-established treatment. One-year survival rates of retroperitoneal sarcomas and lymphomas are approximately $80 \%$ and $67 \%$, respectively, whereas one-year survival rates of undifferentiated tumors and carcinomas are less than 33\% [15]. In pre- 


\section{KOREAN JOURNAL OF OBSTETRICS \& GYNECOLOGY}

Min Ji Ryu, et al. Retroperitoneal squamous cell carcinoma

vious reports similar to our case, chemotherapy with cisplatin and 5-fluorouracil, irrinotecan and cisplatin, paclitaxel and carboplatin or gemcitabine were not effective [8]. In our case, the patient underwent the similar chemotheraphy. However, tumor mass still remains.

We have presented a case of a primary SCC arising from the retroperitoneum that was treated with surgery and adjuvant CCRT with paclitaxel-carboplatin and chemotheraphy. It is difficult to establish the standard treatment of retroperitoneal squamous cell carcinoma for the poor prognosis. In our experience, the role of adjuvant chemotherapy in these tumors is controversial. Complete surgical resection, if possible, is associated with the best prognosis for primary retroperitoneal SCC.

\section{References}

1. Martínez-Piñeiro JA, Pérez-Castro Ellendt $E$, Hernández Armero A, Cisneros Ledo J, Avellana Fontanella JA. Primary retroperitoneal tumors. Apropos of 11 cases. Arch Esp Urol 1983:36:97-108.

2. González Cajigal R, Martín Duce A, Moreno González-Bueno C. Primary retroperitoneal tumors. Rev Esp Enferm Apar Dig 1988;73:580-4.

3. Armstrong JR, Cohn I Jr. Primary malignant retroperitoneal tumors. Am J Surg 1965;110:937-43.

4. Pack GT, Tabah EJ. Primary retroperitoneal tumors: a study of 120 cases. Int Abstr Surg 1954;99:209-31.

5. Pal DK, Chakraborty S, Das S. Retroperitoneal tumours: a ten years retrospective study. J Indian Med Assoc 2005;103:1820.
6. Shimura H, Mihara A, Miyahara H. Statastics of 43 cases of retroperitoneal tumors and the prognosis. J Clin Surg 1964;26:429-35.

7. Liu X, Saiki N, Kohno A, Fujioka M, Hirabayashi K, Komori T, et al. Retroperitoneal squamous cell carcinoma: metastasis from uterine endometrial carcinoma? Radiat Med 2000;18:267-71.

8. Khalil AM, Shabb NS, Hourani MH, Shamseddine Al, El-Hajj MI, Seoud AF. Primary squamous cell carcinoma of the pelvic retroperitoneum presenting as an adnexal mass: a case report. J Obstet Gynaecol 2005;25:92-3.

9. Duncan RE, Evans AT. Diagnosis of primary retroperitoneal tumors. J Urol 1977;117:19-23.

10. Schwarzbach MH, Hormann Y, Hinz U, Leowardi C, Böckler D, Mechtersheimer $G$, et al. Clinical results of surgery for retroperitoneal sarcoma with major blood vessel involvement. J Vasc Surg 2006;44:46-55.

11. Tambo M, Fujimoto K, Miyake M, Hoshiyama F, Matsushita C, Hirao Y. Clinicopathological review of 46 primary retroperitoneal tumors. Int J Urol 2007;14:785-8.

12. An JY, Heo JS, Noh JH, Sohn TS, Nam SJ, Choi SH, et al. Primary malignant retroperitoneal tumors: analysis of a single institutional experience. Eur J Surg Oncol 2007;33:376-82.

13. Boneschi M, Erba M, Cusmai F, Eusebio D, Miani S, Bortolani EM. Primary retroperitoneal tumors. Treatment modality and prognostic factors. Minerva Chir 1999;54:763-8.

14. Chen F, Yang Y, Shi Z, Fu W, Jiang J. Resection of pelvic retroperitoneal neoplasm and reconstruction of iliac blood vessels: report of 22 cases. Zhonghua Wai Ke Za Zhi 2000;38:858-60.

15. Pinson CW, ReMine SG, Fletcher WS, Braasch JW. Longterm results with primary retroperitoneal tumors. Arch Surg 1989;124:1168-73. 


\section{후복막에 월발성으로 생긴 편평상피세포암}

\section{고려대학교 의과대학 산부인과학교실}

유민지, 정예원, 배효숙, 이재관, 이낙우, 송재윤

후복막에 원발성으로 생기는 편평상피세포암(primary retroperitoneal squamous cell carcinoma)은 매우 드문 질환이다. 66세 여성이 한 달 전부터 심해진 우측 다리 통증과 부종으로 내원하였다. Magnetic resonance imaging상 엉덩 혈관(iliac vessels) 주위로 엉덩근(iliacus muscle)과 우측 대퇴골두(femoral head), 폐쇄근(obturator muscle)을 침범하는 종괴가 관찰되었고, 시험적 개복술을 시행하였으나 종괴가 완벽하게 제거되지는 못하였다. 병리조직학적 검사에서 편평상피세포암으로 진단되었고, 환자는 수술 3주 후부터 paclitaxel-carboplatin 과 tomotherapy를 병행하는 항암화학방사선 동시요법을 시행받았다. 그 후 보조 항암화학요법을 7회 추가 시행하였으나 종괴 크기만 7.2 $\mathrm{cm}$ 에서 $6.6 \mathrm{~cm}$ 로 줄어든 양상을 보여 치료 효과는 부분 관해로 판단되었다. 결과적으로 추가적 항암치료의 효과를 단정짓기에는 아직까 지 논란의 여지가 있으며, 종괴의 수술적 제거가 이 질환에서는 더 중요하다고 생각된다.

중심단어: 후복막 종양, 편평상피세포암, 항암화학 동시요법 